\title{
フラッシュランプ励起パルス波色素レーザーによる砕石
}

\section{Laserlithotripsy using the pulsed dye laser}

佐山 孝, 福庭雅洋, 木村 明 *, 森山信男, 東原英二, 阿曾佳郎 石塚雅治 $* *$

Takashi SAYAMA, Masahiro FUKUBA, Akira KIMURA*, Nobuo MORIYAMA, Ei ji HIGASHIHARA, Yoshio ASO, Masaharu I SHI ZUKA**

東京大学医学部泌层器科

都職青山*，浜松ホトニクス俐**

Animal study using the pulsed dye laser at $480 \mathrm{~nm}$ wavelength, $1 \mu \mathrm{sec}$. pulse duration, $159 \mu \mathrm{m}$ core diameter and output energy of $40 \mathrm{~mJ} /$ pulse did not reveal any serious $\mathrm{t}$ issue damage.

The $480 \mathrm{~nm}$ wavelength laserlithotriptor coupled with $9.6 \mathrm{Fr}$. flexible ureterorenoscope was useful for fragmentation of ureteral calculi impacted in the pig ureters.

\section{1. はじめに}

尿路結石破砕のための波長としては，現在 504 $\mathrm{nm}$ が臨休的にも応用され始めている。しかし結 石の反射率を測定してみると,より短波長のレー ザー光の力が結石に吸収され易く，このうち組織 及び血液への吸収率を考虑した $480 \mathrm{~nm}$ 光は組織 障害作用も $504 \mathrm{~nm}$ 光と比べ同程度であることを これまでに報告してきた。今回波長 $480 \mathrm{~nm}$ 光と $504 \mathrm{~nm}$ 光を用い, パルス幅 $1 \mu \mathrm{s}$ のフラッシュラ ンプ励起パルス波色素レーザーにて，実際に稀腎 雷に埋め込んだヒト尿路結石に対し，軟性尿管鏡 を用いた䃏石を試みた。また，導光ファイバーの コア径の違いによる衝慗波の強さについても検討 したので，合わせて報告する。
2. 目的

I . 豚体内での波長 $480 \mathrm{~nm}$ 光と $504 \mathrm{~nm}$ 光によ る砕石効果の比較

II. 軟性尿管鏡の使用に伴う尿路上皮の変化の 観察

III. 導光ファイパーのコア径（直径）の違いに よる衝撃波強度の比較

3. 方法 (I.II.)

(1) 静脈麻酔下，七卜尿路結石を雌仔豚腎监に 腰部斜切開にて埋め込み

(2) 経尿道的に $9.6 \mathrm{Fr}$ ，軟性层管鏡を挿入

(3) $480 \mathrm{~nm}$ と $504 \mathrm{~nm}$ 光を照射 L砕石

(4) 結石介在部, 生理的狭窄部を光顕的に観察 
(5) $9.5 \mathrm{Fr}$ 硬性尿管鏡捙入に伴う生理的狭窄 部の变化を光顕的に観察

\section{4. 結 果}

砕石には，ヒト尿路結石（リン酸カルシウム結 石 $\mathrm{Ca} \cdot \mathrm{P})$ を用い,臨床応用を意識した砕石とした。 $480 \mathrm{~nm}$ 光と $504 \mathrm{~nm}$ 光をコア径 $300 \mu \mathrm{m}$, 先端出力

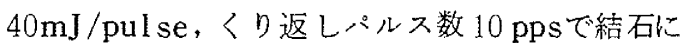
照射し，結石が $2 \sim 3 \mathrm{~mm}$ 大の砕石片に分かれた 時点を終了とした。結石の各々の形状・硬度はや や異なり，技術的な要因もあるため，挽石に要し たパルス数にはかなりのバラッキがあり $480 \mathrm{~nm}$ 光で平均 400 パルス前後, $504 \mathrm{~nm}$ 光で平均 500 パス前後であった。実際に型通りの砕石が施行 されたもののうち, 各々 5 例の結果を図 1 に示し た。

軟性尿管鏡で実際の碎石を行い，硬性鏡では砕 石を行なわずに覒入のみとした。9.5Fr．の細径 の硬性鏡を用い，軟珄鏡の場合と同じく尿管の抎 張をせずに挿した。図2 2 ，軟性鏡の使用に伴う 尿管壁の变化の光影像である。

導光ファイパーのコア径の逢いによる衝慗波の 強さの測定法を図 $3 に$ 示した。先端出力を $15 \mathrm{~mJ}$, $20 \mathrm{~mJ}, 30 \mathrm{~mJ}$ とし, コア径 $159 \mu \mathrm{m}, 300 \mu \mathrm{m}$, $400 \mu \mathrm{m}$ の 3 本のクオーッファイパーを用いた。 $600 \mathrm{~nm}$ 付近より短波長域の吸収が高い赤色プラ スチック板にレーザー光を照射し, 発生した衝撃 波による生力波をプラスチック板より $2 \mathrm{~mm}$ 離れ た位置に固定したピエゾ素子により電王の変化と して捕えた。図4に示すように，同一出力ではコ ア径が細いもの程エネルギー密度が高いため強い 印力波を発生した。図 5 は, この場合の面積比, 即ちェネルギ一密度比の逆数でもあるが，これを 横軸にとって表したものである。コア径 $159 \mu \mathrm{m}$ の面積は, コア径 $400 \mu \mathrm{m}$ のものの 6.3 倍となり 従ってェネルギ一密度は $1 / 6.3\left(2.4 \times 10^{4} \mathrm{~mJ} /\right.$ $\mathrm{cm}^{2}$ ) に低下し，これに伴い王力波も $159 \mu \mathrm{m}$ の 場合の $1 / 2$ に低下した。

\section{5. まとめ}

導光ファイバー径が細いと, 同一出力ではェネ ルギー密度が高くなるため強い衝撃波を発生する。 また結石の凹凸面に先端が入り込み有効な确石が 期待できる。従って，尿管の拉張を要せずに尿管 に挿入できる軟性尿管鏡を組み合わせた波長 480 $\mathrm{nm}$ ，コア径 $159 \mu \mathrm{m}$ の細い径のファイバーを用い たパルス・レーザー碎石器は, 現在臨床に用いら れている波長 $504 \mathrm{~nm}$ ，コア径 $200 \mu \mathrm{m}$ のもと比 べ，同等以上の効果が期待できると考えられた。 今後, コア径の細いファイハー一の操作性の改善を 図ると其に，愦照射の防止，眼精疲労の軽減のた めに結石と組織の識別を、レーザ一照射を行なお ずとも可能とするシステムの開発を進め,より安 全でより容易な砕石法の確立をめざしていきたい と考えている。

\begin{tabular}{|c|c|c|c|c|}
\hline 波長 & No. & 結石径 (mm) & バルス数 & 結 果 \\
\hline \multirow{5}{*}{$480 \mathrm{~nm}$} & 1 & $4 \times 6$ & 216 & 0 \\
\hline & 2 & $5 \times 7$ & 1000 & 砕石不可 \\
\hline & 3 & $5 \times 5$ & 83 & 0 \\
\hline & 4 & $6 \times 7$ & 413 & 0 \\
\hline & 5 & $5 \times 8$ & 965 & $\mathrm{O}$ \\
\hline \multirow{5}{*}{$504 \mathrm{~nm}$} & 1 & $5 \times 7$ & 557 & 0 \\
\hline & 2 & $4 \times 8$ & 272 & 0 \\
\hline & 3 & $5 \times 5$ & 683 & 0 \\
\hline & 4 & $5 \times 8$ & 581 & 0 \\
\hline & 5 & $4 \times 7$ & 1200 & 甜石不可，尿管第孔 \\
\hline
\end{tabular}

図1、豚を用いた砕石実験

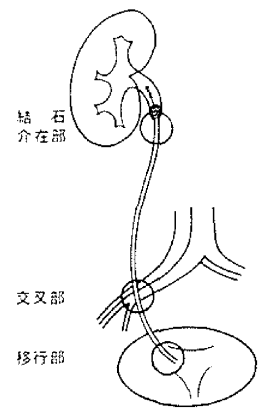

\begin{tabular}{|c|c|c|}
\hline & 軟性鏡 & $\begin{array}{c}\text { 硬性鏡 } \\
\text { (㧫入のみ }\end{array}$ \\
\hline 口 径 & $9.6 \mathrm{Fr}$ & $9.5 \mathrm{Fr}$ \\
\hline $\begin{array}{l}\text { 结 石 } \\
\text { 介在暗 }\end{array}$ & 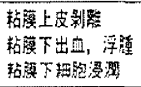 & - \\
\hline 交文部 & 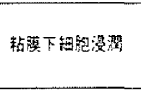 & 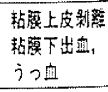 \\
\hline 移行部 & 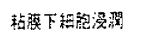 & 耛灌上皮新露 \\
\hline
\end{tabular}

図2，尿管の部位による組織障害 $(n=2)$ 


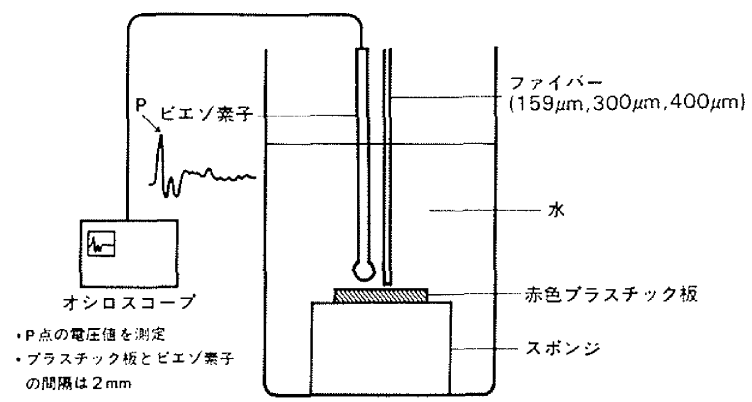

図3、ファイバーのコア径による衝波の測定

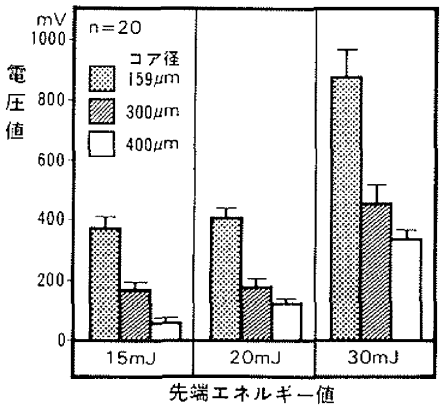

図4.ファイバーのコア径の違いによる衝繁波比較

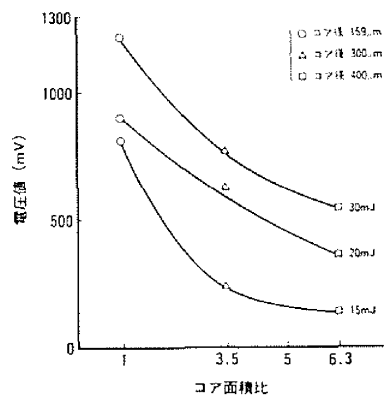

( 27 传 159 \%

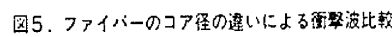

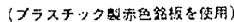

